\title{
Exceptionally strong year classes in plaice Pleuronectes platessa: are they generated during the pelagic stage only, or also in the juvenile stage?
}

\author{
Henk W. van der Veer ${ }^{1 *}$, Audrey J. Geffen ${ }^{2}$, Johannes IJ. Witte ${ }^{1}$ \\ ${ }^{1}$ Netherlands Institute for Sea Research (NIOZ), PO Box 59, 1790 AB Den Burg Texel, The Netherlands \\ ${ }^{2}$ Port Erin Marine Laboratory, University of Liverpool, Isle of Man IM9 6JA, United Kingdom
}

\begin{abstract}
The exceptionally strong 1996 year class of plaice Pleuronectes platessa L. at the Balgzand in the western Dutch Wadden Sea offered the opportunity to study whether such a strong year class is generated and determined only during the pelagic stage, or also in the juvenile stage. This was done by comparing the 1996 year class with other years (1993 to 1999), including a weak year class (1995). Larval immigration in 1996 was delayed by about $1 \mathrm{mo}$, compared to 1995 . A significant relationship existed between reconstructed water temperature during developmental drift and the abundance of settling larvae. Estimation of the hatch date distribution of the larvae by means of otolith microstructure analysis showed that in 1996 the settling flatfish mainly originated from eggs hatched in February and March, while in the weak 1995 year class the larvae originated from eggs hatched in January and February. Mortality during the first months after settlement was density-dependent; however, in 1996 this relationship broke down and mortality was much lower than expected. After the severe winter of 199596. predatory crustaceans were absent in the nursery and as a consequence the already extremely strong year class of 1996 passed through this period of mortality relatively unharmed. These results confirmed earlier observations that when an extremely strong year class is generated after a very cold winter, the regulative mechanism of density-dependent predation in the nursery--which normally dampens interannual variability in abundance - may fail due to low abundance of predatory crustaceans.
\end{abstract}

KEY WORDS: Pleuronectes platessa $\cdot$ Cold winter $\cdot$ Control $\cdot$ Flatfish $\cdot$ Hydrography $\cdot$ Otolith microstructure $\cdot$ Regulation $\cdot$ Temperature $\cdot$ Year-class strength

\section{INTRODUCTION}

Extensive studies on Southern Bight plaice Pleuronectes platessa $\mathrm{L}$. have provided evidence that variability in year-class strength is generated during the pelagic egg and larval stages (Brander \& Houghton 1982, Zijlstra et al. 1982, Van der Veer 1986, Van der Veer \& Witte 1999). This coarse control in the plankton is followed by a fine regulation during the juvenile stage by density-dependent mortality during the phase shortly after settlement in the nursery areas, whereby the variability in interannual recruitment is dampened (Van der Veer 1986, Beverton \& Iles 1992a,b).

The mechanisms behind this coarse control in the planktonic phase and fine regulation in the demersal

\footnotetext{
•E-mail: veer@nioz.nl
}

phase have only been partly explained. Year-class strength of plaice appeared to be inversely related to the temperature conditions during egg and larval drifts, suggesting that variations in the mortality rates of eggs and larvae during planktonic drift might be important (Van der Veer 1986, Van der Veer \& Witte 1999). On the other hand, interannual variability in the hydrodynamic circulation between spawning and nursery grounds also appears to be a key factor (Nielsen et al. 1998, Van der Veer et al. 1998, Van der Veer \& Witte 1999). The fine regulation during the subsequent demersal stage is caused by density-dependent mortality by predatory crustaceans, the brown shrimp Crangon crangon and the shore crab Carcinus maenas on just-settled plaice (Van der Veer \& Bergman 1987).

The interannual variability in year-class strength of plaice is extremely low, in the order of 20 to $40 \%$ (for 
recruitment time series see Rijnsdorp et al. 1991). However, once in a while after a very cold winter, an exceptionally strong year class is generated. In this respect, the 1963 plaice year class is still known as being among the strongest year classes ever observed. The strength of the 1963 year class appeared to be generated and maintained by processes active during the planktonic egg and larval stages (Harding et al. 1978). Van der Veer (1986) states that strong year classes are especially generated by large numbers of late arriving larvae, suggesting differences in survival and origin of the larvae. In addition, Van der Veer \& Bergman (1987) suggest that, in the case of an extremely strong year class, the regulative mechanism after settlement in the nursery might fail. A severe winter may decimate the populations of predatory crustaceans and as a consequence an already strong year class will pass through this period of predation relatively unharmed. So far, these suggestions are mainly anecdotal and speculative because there have been no such strong year classes since 1963 .

The very cold winter of 1995-96 resulted in an exceptionally strong year class of plaice. Densities in the Balgzand nursery in 1996 were higher than ever observed before, with peak densities of over 1 ind. $\mathrm{m}^{-2}$ (Van der Veer \& Witte 1999). This 1996 year class offers the opportunity to analyse whether such an exceptionally strong year class is generated only by pelagic stage processes, or also by factors acting in the juvenile stage. In this paper we tried to answer this question by analysing the following aspects: (1) the origin of immigrating larvae by estimating the hatch date distributions by means of otolith microstructure analysis; (2) the pattern of larval immigration over time; and (3) whether the regulative mechanism in the nursery has failed or not. For the analysis, the extremely strong 1996 year class was compared with a relatively weak year, the 1995 year class. In addition, relevant information on plaice and predatory crustaceans for other years over the period 1993 to 1999 are presented.

\section{MATERIAL AND METHODS}

Sampling. All information on plaice and predatory crustaceans was collected at a large isolated tidal flat system in the western Dutch Wadden Sea, Balgzand (Fig. 1). Fishing was carried out from March onwards at frequent intervals ( 2 to $4 \mathrm{wk}$ ) on a grid of 36 stations distributed over the area at a period of $3 \mathrm{~h}$ around high water, since during this period the population is randomly distributed over the area (Kuipers 1977). Hauls of about $100 \mathrm{~m}$ in length were undertaken during daytime with a $1.9 \mathrm{~m}$ beam trawl (1 tickler chain, net mesh size of $5 \times 5 \mathrm{~mm}$ ) towed by a rubber dinghy with a
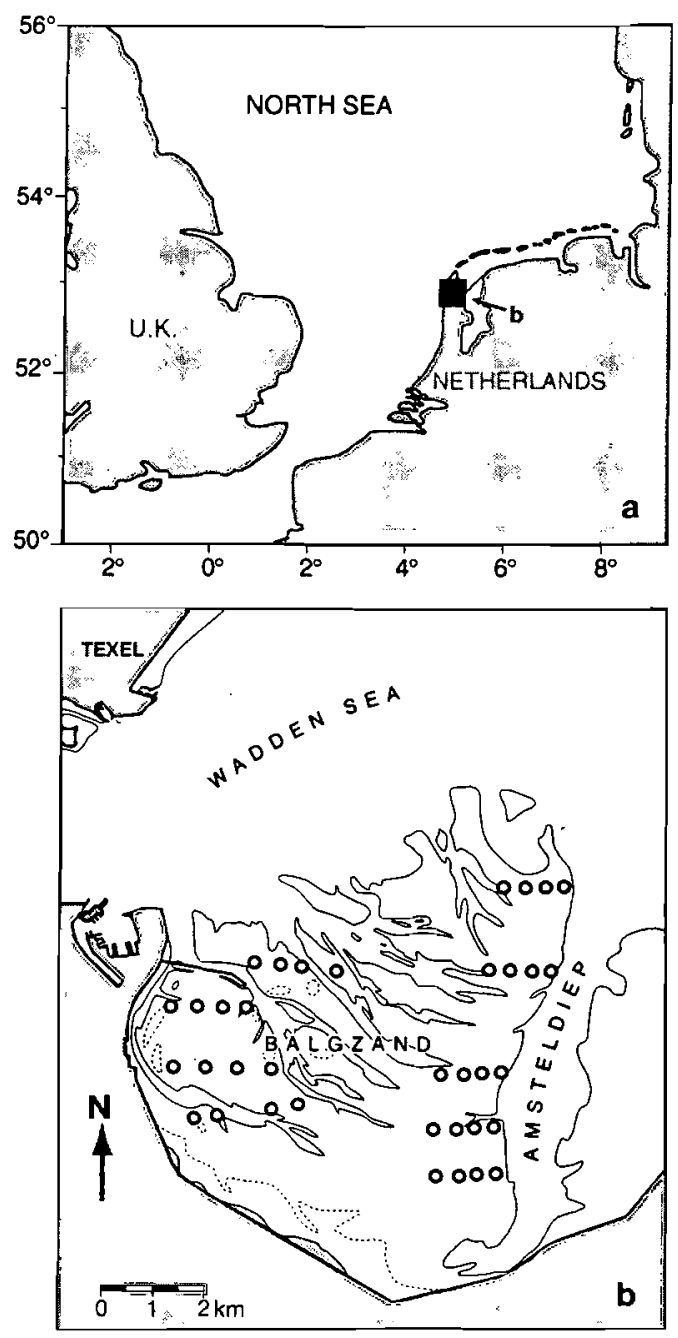

Fig. 1. Location of the Balgzand tidal flat area, together with sampling stations (0)

25 HP outboard motor at a speed of approximately $35 \mathrm{~m} \mathrm{~min}^{-1}$ (Riley \& Corlett 1966). Location of the hauls was established by the global positioning system and the length of the hauls was assessed with a meterwheel fitted to the trawl. Catches were deep-frozen and then sorted within a few days. 0-group plaice and crustaceans were preserved in $70 \%$ ethanol. Plaice was measured to the nearest $\mathrm{mm}$ total length. Shrimps were measured to the nearest $0.5 \mathrm{~cm}$ total length and shore crabs to the nearest $0.5 \mathrm{~cm}$ carapace width. For plaice, numbers caught were corrected for sizeselective mesh and catch efficiency after Kuipers (1975) and Dapper (1978) and converted into numbers per $1000 \mathrm{~m}^{2}$ (ind. $\left[10^{3} \mathrm{~m}^{2}\right]^{-1}$ ). Catches of shrimp and crab were not corrected for mesh and catch efficiency and the number caught were also converted into numbers per $1000 \mathrm{~m}^{2}$ (ind. $\left[10^{3} \mathrm{~m}^{2}\right]^{-1}$ ). The arithmetic mean of all stations sampled during a survey was calculated 
as an index of abundance. For more information see Zijlstra et al. (1982) and Van der Veer (1986). Previous research has indicated that the $95 \%$ confidence limits of the arithmetic mean are in the order of $35 \%$ of the mean (Zijlstra et al. 1982).

Data analysis. Previous research has shown that immigrating plaice larvae vary in size from 10 to $15 \mathrm{~mm}$ (Van der Veer 1986). Also, densities of immigrating and settling pelagic larvae appeared to be significantly related to the numbers of demersal settled plaice $\leq 15 \mathrm{~mm}$ (Van der Veer 1986). Therefore, information on larval abundance was reconstructed from data on settled plaice $\leq 15 \mathrm{~mm}$. For each cruise in 1995 and in 1996, the mean density of settled plaice $\leq 15 \mathrm{~mm}$ was estimated and this was considered to reflect the pattern of immigrating larvae. Developmental temperatures during egg and larval drifts were reconstructed from NOAA satellite images of sea surface temperatures. This information has been taken from Van der Veer \& Witte (1999). For 1995 and 1996 a random sample of settling larvae was taken from the various cruises, weighted in relation to the abundance of larvae during each cruise. The sagittal otoliths were removed from the selected fish and mounted for microstructure analysis of daily increments. The preparation of the otolith was carried out according to the standard techniques described in Secor et al. (1991) and in Stevenson \& Campana (1992). Series of light micrographs at magnifications between $100 \times$ and $2500 \times$ were used for increment analysis. At least 4 counts of the number of daily increments were made along various radial lines. If the difference between one of the counts and the mean exceeded $10 \%$, the otolith was removed from further analysis. In total, 98 otoliths were analysed for 1995 and 132 for 1996.

Mortality rates of 0 -group plaice during the demersal stage were estimated according to the protocol of lles \&

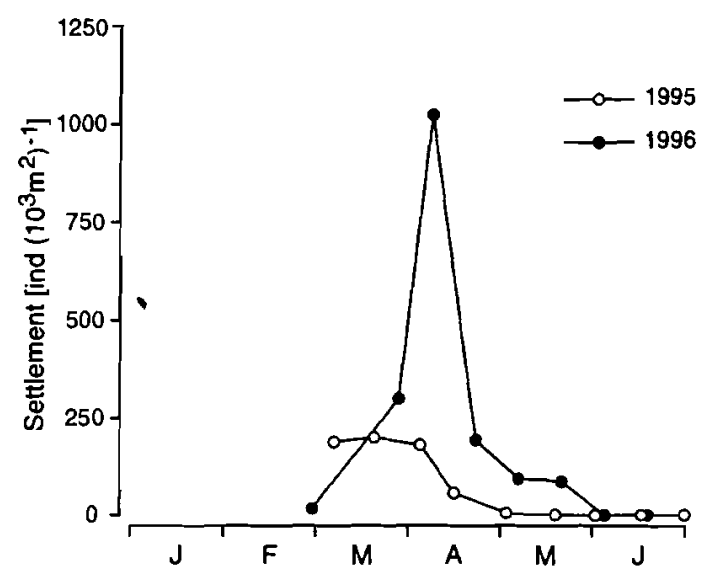

Fig. 2. Pleuronectes platessa. Pattern of immigrating plaice larvae at Balgzand (ind. $\left[10^{3} \mathrm{~m}^{2}\right]^{-1}$ ) in 1995 and in 1996 based on the densities of just-settled individuals $(\leq 15 \mathrm{~mm})$
Beverton (1991). The natural logarithm of the average estimated density was plotted against date of sampling for each of the cruises. For each year the mortality rate $\left(M_{i} \mathrm{~d}^{-1}\right)$ was estimated from the slope of the linear regression. These estimates were restricted to the period from peak settlement until the beginning of July. In addition to the estimates for 1995 and 1996, information is provided for the years 1993 to 1999. All analyses were performed with SYSTAT (Wilkinson 1989).

\section{RESULTS}

\section{Pelagic phase}

The pattern of larval immigration differed between 1995 and 1996, not only with respect to density but also with respect to timing (Fig. 2). The peak density of the extremely strong year class of 1996 was about 5 times higher than that in 1995. The data indicated that immigration in 1995 had already started in February, while in 1996 it did not start before the beginning of March. Furthermore, in 1995 peak numbers occurred in March at Julian Day 78 and in 1996 the peak was not observed before the beginning of April at Julian Day 98. Also, the end of larval immigration differed substantially between 1995 and 1996. In 1995 it stopped at the end of April, and in 1996 it continued until the end of May. In the extremely strong year class of 1996 , immigration seemed to be delayed by about $1 \mathrm{mo}$. In both years the abundance of immigrating larvae was significantly related to the reconstructed water temperatures during

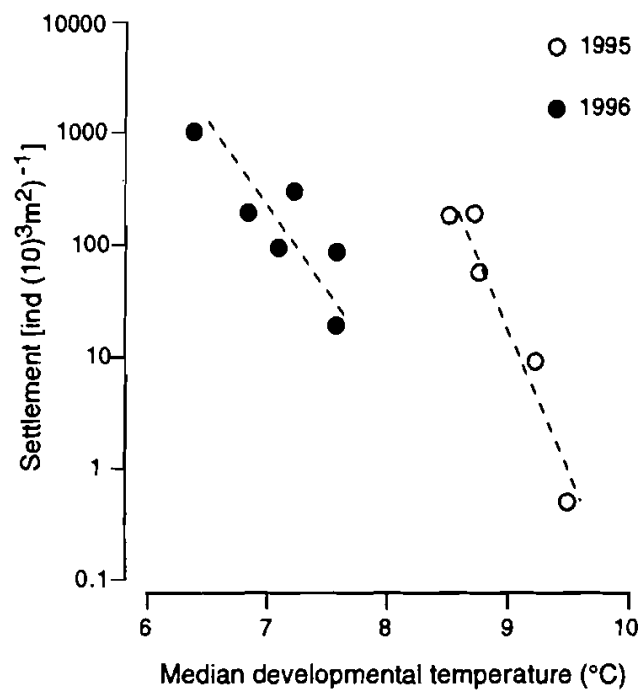

Fig. 3. Pleuronectes platessa. Relationship between median water temperature $\left({ }^{\circ} \mathrm{C}\right)$ during development and number of settling plaice larvae (ind. $\left[10^{3} \mathrm{~m}^{2}\right]^{-1}$ ) at Balgzand during a weak year (1995) and an extremely strong year (1996). For more information see text 
Table 1. ANOVA of abundance of settling larvae $\left\{\ln A b u n ; \ln \left(i n d .\left[10^{3} \mathrm{~m}^{2}\right]^{-1}\right)\right\}$ at Balgzand in relation to reconstructed water temperature during drift $\left(\mathrm{Temp}^{\circ}{ }^{\circ} \mathrm{C}\right.$ ) in 1995 and 1996 (Year), according to the model: $\ln A$ bun $=$ Constant + Year $\times$ Temp + Year + Temp. Dep Var $=\ln A$ bun, $N=11$, multiple $R=0.947$, multiple $\mathrm{R}^{2}=0.896$, Adjusted multiple $\mathrm{R}^{2}=0.852, \mathrm{SE}$ of estimate $=0.794$

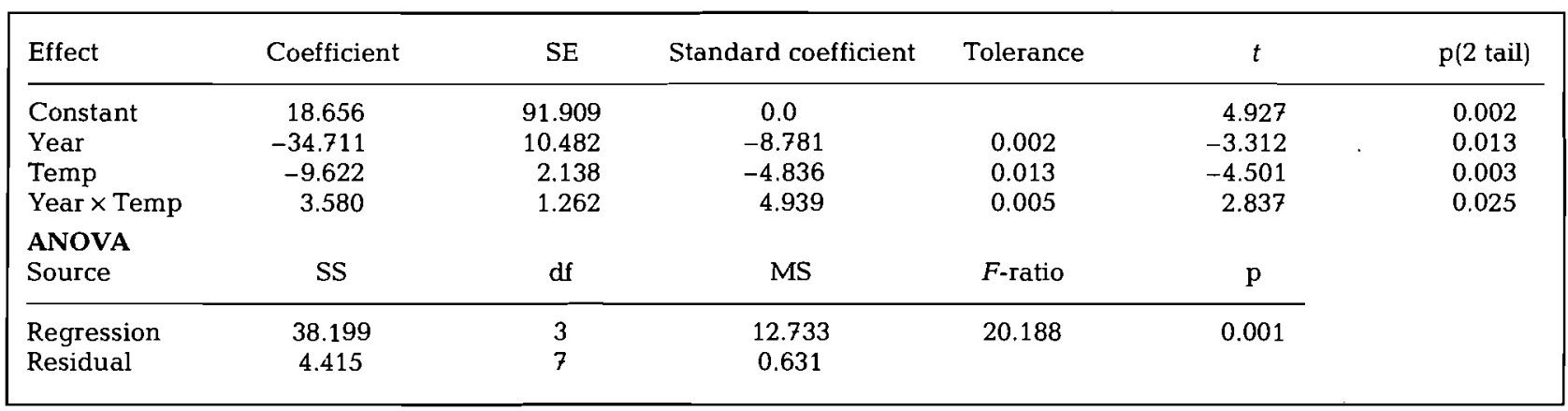

development (Fig. 3); however, the slope in both years was significantly different (ANOVA, Table 1):

$$
\begin{aligned}
& \text { 1995: } \ln S=-6.042 T+57.2\left(\mathrm{r}^{2}=0.93\right) \\
& \text { 1996: } \ln S=-2.461 T+22.5\left(\mathrm{r}^{2}=0.71\right)
\end{aligned}
$$

where $\ln S$ is the natural logarithm of density of settling larvae (ind. $\left[10^{3} \mathrm{~m}^{2}\right]^{-1}$ ) and $T$ is median water temperature during development $\left({ }^{\circ} \mathrm{C}\right)$.

The back-calculated hatch distributions of the immigrating plaice larvae from the otolith microstructure analysis are presented in Fig. 4. In both years, the hatch distribution shifted over the period of immigration, respectively from January to February in 1995 and from February to March in 1996. In combination with the absolute numbers of larvae immigrating over time (Fig. 2), the overall hatch distribution of both year classes could be estimated by multiplying the hatch distribution with the absolute numbers for each sampling date and summing them up (Fig. 5). In 1995 the hatch distribution ranged from the beginning of January to the end of February, with a peak in the second half of January. The hatch distribution in 1996 differed significantly from that in 1995, it ranged from the end of January to the beginning of April with a peak at the end of February. The corresponding spawning distribution in both years was 2 wk earlier, assuming a median temperature of $7^{\circ} \mathrm{C}$ during egg development in 1995 and 1996 (see Fig. 6 in Van der Veer \& Witte 1999).

\section{Demersal phase}

Fig. 6a shows the seasonal pattern of abundance of 0-group plaice (including the just-settled individuals

\begin{tabular}{|c|c|c|c|c|c|c|c|c|c|}
\hline Year & $t_{\max }$ & $t_{\text {end }}$ & $D_{\max }$ & $v$ & $a$ & $M$ & $\mathrm{SE}_{M}$ & $\mathrm{R}^{2}$ & $p$ \\
\hline 1993 & 117 & 172 & 370 & 5 & 9.679 & 0.034 & 0.005 & 92 & 0.006 \\
\hline 1994 & 108 & 179 & 375 & 6 & 9.252 & 0.030 & 0.005 & 89 & 0.003 \\
\hline 1995 & 94 & 166 & 244 & 6 & 8.339 & 0.029 & 0.002 & 97 & 0.001 \\
\hline 1996 & 98 & 154 & 1282 & 5 & 9.065 & 0.021 & 0.003 & 90 & 0.010 \\
\hline 1997 & 100 & 160 & 453 & 5 & 9.231 & 0.031 & 0.004 & 92 & 0.006 \\
\hline 1998 & 91 & 151 & 262 & 5 & 7.721 & 0.023 & 0.007 & 72 & 0.043 \\
\hline 1999 & 83 & 131 & 312 & 3 & 7.690 & 0.022 & 0.007 & 83 & 0.190 \\
\hline \multicolumn{10}{|c|}{ Explanation of symbols } \\
\hline Symbol & Dimension & & \multicolumn{7}{|c|}{ Interpretation } \\
\hline$t_{\max }$ & \multirow{2}{*}{\multicolumn{2}{|c|}{$\begin{array}{l}d \\
d\end{array}$}} & \multicolumn{7}{|c|}{ Time of maximum observed density from 1 January } \\
\hline$t_{\text {end }}$ & & & \multicolumn{7}{|c|}{ Time of final sampling included in regression calculations } \\
\hline$D_{\max }$ & \multicolumn{2}{|l|}{ ind $\left(10^{3} \mathrm{~m}^{2}\right)^{-1}$} & \multicolumn{7}{|c|}{ Maximum observed density } \\
\hline$v$ & \multirow{2}{*}{\multicolumn{2}{|c|}{ In (ind $\left[10^{3} \mathrm{~m}^{2} \mathrm{l}^{-1}\right.$ ) }} & \multicolumn{7}{|c|}{ Number of dates for which data are included in regression calculations } \\
\hline$a$ & & & \multicolumn{7}{|c|}{ Constant of regression equation } \\
\hline$M$ & \multicolumn{2}{|l|}{$d^{-1}$} & \multicolumn{7}{|c|}{ Slope of regression equation } \\
\hline $\mathrm{SE}_{M}$ & & \multicolumn{7}{|c|}{ Estimated standard error of $M$} \\
\hline $\mathbf{R}^{2}$ & \multirow{2}{*}{\multicolumn{2}{|c|}{$\%$}} & \multirow{2}{*}{\multicolumn{7}{|c|}{$\begin{array}{l}\text { Proportion of variation accounted for by regression equation } \\
\text { Significant level associated with test of } M=0\end{array}$}} \\
\hline $\mathrm{p}$ & & & & & & & & & \\
\hline
\end{tabular}

Table 2. Maximum density, mortality and associated statistics of 0-group plaice at Balgzand for the period 1993 to 1999 
Fig. 4. Pleuronectes platessa. Hatching date frequency distribution (ind.) of plaice larvae at Balgzand over the period of immigration in 1995 and in 1996, based on otolith microstructure analysis
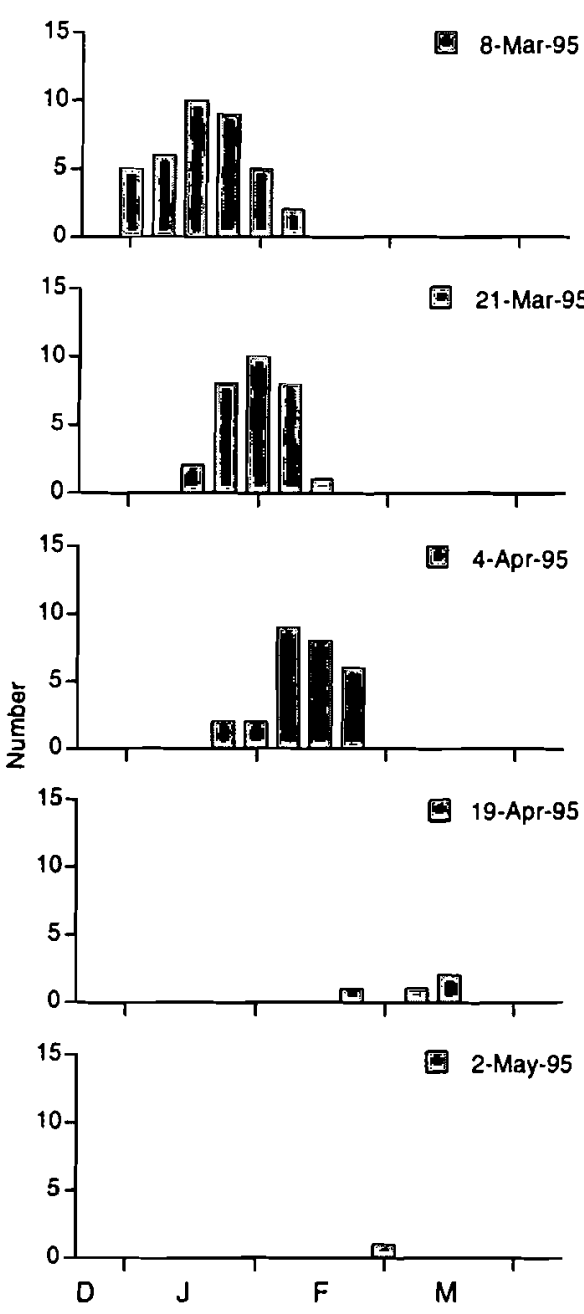
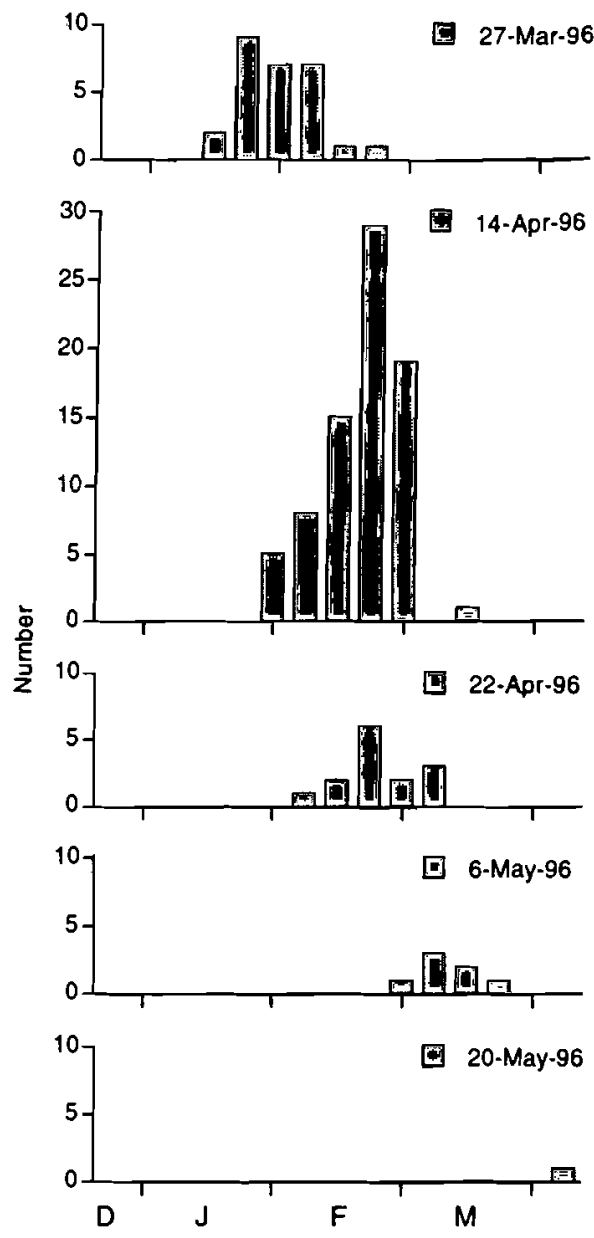

$\leq 15 \mathrm{~mm}$ ) at the Balgzand in 1993 to 1999 . Peak density of settled plaice in the extremely strong 1996 year class was also about 5 times that in 1995. Over the years, the mean instantaneous mortality rate $(M)$ from peak density to the beginning of June differed between 0.021 and $0.034 \mathrm{~d}^{-1}$, and the lowest $M$ was observed in 1996 (Table 2). Peak density and $M$ were positively correlated (Fig. 6b), only when the estimate for 1996 was excluded:

$$
M_{t}=0.017+0.000034 \times D_{t}\left(\mathrm{r}^{2}=0.57\right)
$$

where $M_{t}$ is the instantaneous mortality rate $\left(\mathrm{d}^{-1}\right)$ in Year $t$ and $D_{t}$ is peak density (ind. $\left[10^{3} \mathrm{~m}^{2}\right]^{-1}$ ) in Year $t$. This implied that in 1996, $M$ was much lower than predicted by the observed (density-dependent) relationship between peak density and $M$.

The seasonal abundance of the predatory crustaceans (brown shrimps $>30 \mathrm{~mm}$ total length and shore crabs $>30 \mathrm{~mm}$ carapace width after Van der Veer \& Bergman 1987) showed clear differences between warm and cold winters (Fig. 7). Since no data are available for 1995, information from 1993 was taken, after

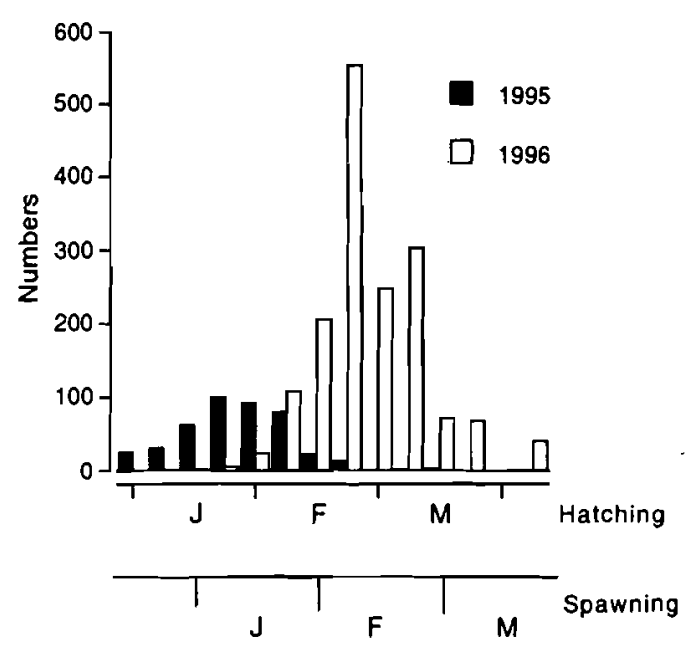

Fig. 5. Pleuronectes platessa. Relative spawning and hatching date frequency distribution (ind.) of plaice larvae for the weak 1995 and the extremely strong 1996 year classes at Balgzand, based on a combination of the information in Figs. $2 \& 4$. Differences in individuals indicate differences in relative abundance between years 

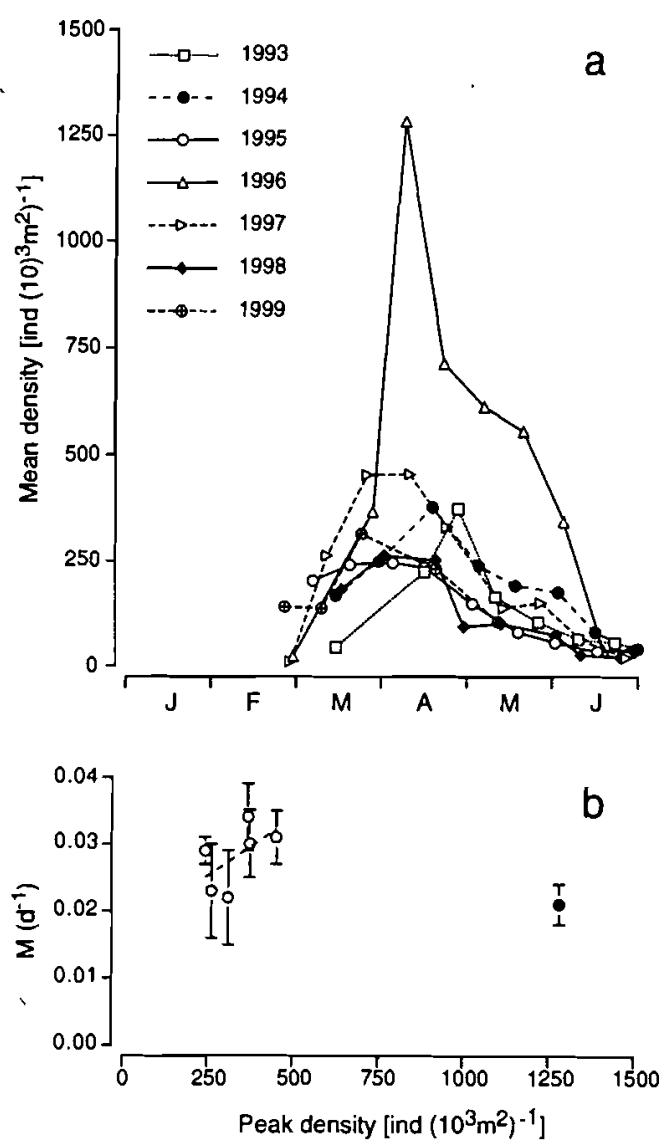

Fig. 6. Pleuronectes platessa. (a) Seasonal pattern of density (ind. $\left[10^{3} \mathrm{~m}^{2}\right]^{-1}$ ) of 0 -group plaice at Balgzand for the years 1993 to 1999. (b) Relationship between peak density of plaice in spring (ind. $\left[10^{3} \mathrm{~m}^{2}\right]^{-1}$ ) and mean instantaneous mortality rate $\left(M_{i} \mathrm{~d}^{-1}\right)$, together with standard error from the moment of peak density to the beginning of June for the years 1993 to 1999, excluding $1996(\bullet)$

the relatively warm winter of 1992-93 (Van der Veer \& Witte 1999). Both predators showed a delay in presence after the extremely cold winter. In the shore crab this delay amounted about $1.5 \mathrm{mo}$; however, in the brown shrimp it was less (ca $3 \mathrm{wk}$ ). These differences were not caused by differences in actual water temperature on the nursery ground (Fig. $7 \mathrm{c}$ ). From the end of March onwards, water temperature at Balgzand was similar both after the relatively warm 1992-93 winter and after the extremely cold 1995-96 winter.

\section{DISCUSSION}

\section{What is exceptional in an exceptionally strong year class?}

The results of this study clearly illustrate that an exceptionally strong year class of plaice differs from
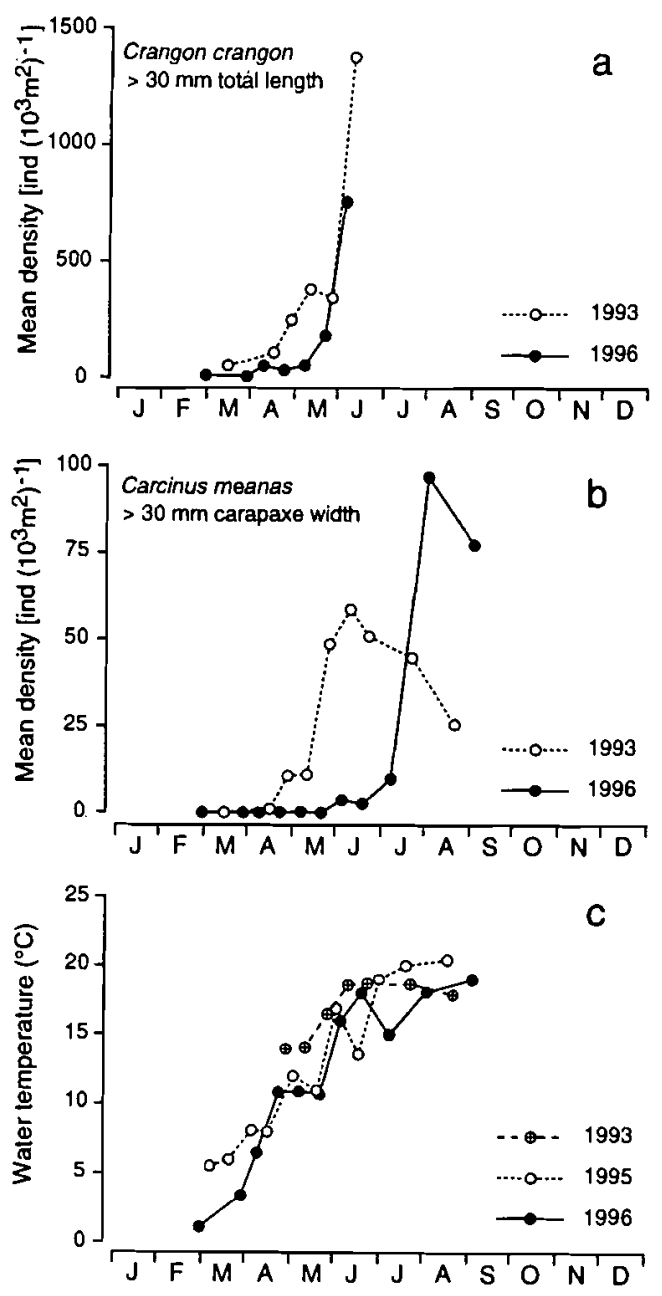

Fig. 7. (a) Seasonal pattern of density (ind. $\left[10^{3} \mathrm{~m}^{2}\right]^{-1}$ ) of predatory shrimps Crangon crangon (>30 mm total length) at Balgzand after a relatively warm winter (1993) and an extremely cold winter (1996). (b) Seasonal pattern of density (ind. $\left[10^{3} \mathrm{~m}^{2}\right]^{-1}$ ) of predatory shore crabs Carcinus maenas (>30 mm carapace width) at Balgzand after a relatively warm winter (1993) and an extremely cold winter (1996). (c) Seasonal pattern of water temperature $\left({ }^{\circ} \mathrm{C}\right)$ at Balgzand after relatively warm winters $(1993,1995)$ and an extremely cold winter (1996)

other years in at least 3 aspects: the temporal pattern of larval immigration into the nursery over time; the origin of the immigrating larvae and the absence of regulatory mechanisms (density-dependent mortality) in the nursery after settlement.

In the extremely strong 1996 year class, the pattern of larval immigration showed a delay of about 1 mo. Since this exceptionally strong year class was generated after a very cold winter, this delay in immigration can fully be explained by a reduced water temperature. To some extent the onset of spawning might be delayed too (Rijnsdorp \& Vethaak 1997); however, the main factor will have been the reduced water temper- 
ature during drift and hence the longer period of development (Van der Veer \& Witte 1999). In both the normal 1995 and the exceptionally strong 1996 year classes, the abundance of immigration larvae was strongly related to prevailing water temperature during development. Although the number of eggs spawned might have been different between 1995 and 1996 due to variability in size-specific fecundity and in spawning biomass (Rijnsdorp 1994), the significant negative relationship in both years between number of settling larvae and water temperature during drift suggests that temperature conditions influence the survival rate of the eggs and larvae. The occurrence of malformations in plaice eggs also appears to be directly and inversely related to prevailing water temperature (Von Westernhagen \& Dethlefsen 1997); however, within the temperature range observed in 1995 and 1996 from about 6 to $10^{\circ} \mathrm{C}$ the occurrence of malformations is low and independent of temperature. Therefore, the relationship with temperature will more likely be an indirect one acting via either predation or starvation (match/mismatch). Since egg mortality is also clearly related to egg size, both between and within plaice and cod (Rijnsdorp \& Jaworski 1990), predation seems to be the most likely candidate. The strongest inverse relationship was observed in 1995 at relatively high temperatures. This difference in slope between the 2 years maybe suggests that at high temperatures in 1995 starvation also adds to the overall mortality, or that at the low temperatures (1996) predators become inactive or emigrate out of the area.

The origin of the immigrating larvae also showed a clear difference between the weak 1995 and strong 1996 year classes. The reconstructed spawning distribution illustrates that whereas in 1995 immigrating larvae originate from egg batches spawned in late December and January, in the extremely strong 1996 year class the main contribution is from the batches spawned from the end of January to the beginning of March. Van der Veer \& Witte (1999) argued based on published information on egg and larval drift (Harding et al. 1978) that in both years the larvae originated from the Southern Bight spawning grounds. These findings are in contradiction with Hovenkamp (1991), who suggested that after a cold winter the larvae had already hatched in December and probably originated from the English Channel.

In plaice there are a number of trends during spawning (Rijnsdorp 1989, 1994): (1) as they grow older female plaice spawn earlier in the season; (2) egg production and egg size increases with body size and age; (3) during spawning the egg size of the various batches decreases over time. This suggests that in the weak 1995 year class the immigrating larvae originated from relatively large eggs from the older females, whereas in the exceptionally strong 1996 year class the larvae might have also originated from smaller eggs spawned by the younger females. These differences clearly show that egg survival varies strongly over the spawning season and also over the years. This illustrates that the time window of spawning in the Southern Bight is a clear reflection of the interannual variability in both temperature and hydrography during egg and larval drifts.

After settlement of the larvae, the mortality among the 0-group plaice is strongly density-dependent. This finding supports the conclusion of Iles \& Beverton (1991), which was based on an analysis of previous data over the period 1974 to 1982 . Field and laboratory observations have shown that this density-dependent mortality is caused by predation by brown shrimps and shore crabs (Van der Veer \& Bergman 1987). This regulative mechanism of density-dependent predation in the nursery, which dampens interannual variability in abundance, is also operating in the weak 1995 year class. However, it is absent in the exceptionally strong 1996 year class after the cold winter due to the almost complete absence of the predatory crustaceans in spring. Beukema $(1991,1992)$ found that after a relatively cold winter the abundance and biomass of both brown shrimps and shore crabs were reduced and increased later than after a relatively warm winter. The data in 1996 support this view. Predatory shrimps did not arrive until the end of May and predatory crabs were almost absent until the end of June. This resulted in the fact that in $1996 M$ was much lower than expected according to the observed (density-dependent) relationship between peak density and mortality and that the regulating mechanism was absent for this exceptionally strong year class.

\section{At what spatial scale are these exceptionally strong year classes generated?}

Very cold winters generating extremely strong year classes do not occur frequently. In plaice, 1947 and 1963 are recognised as extremely strong year classes (Harding et al. 1978). However, quantitative studies on demersal 0-group were rare at that time, and only limited information about mortality in plankton during the egg stage is available (Harding et al. 1978). Furthermore, information is restricted to the Southern Bight population, and hence it remains unclear whether these exceptionally strong year classes were generated only at a local scale or whether they did occur on a broader spatial scale. The fact that the 1963 year class was not a strong one at the Scottish fishing grounds (Rauck 1974) suggests that the generation of an exceptionally strong year class was at least limited to a restricted part of the nursery grounds of plaice. 
With respect to the 1996 year class the situation is different. Information about the pelagic stage is lacking, but there is detailed information of the demersal stage for a number of nursery areas in Europe. In Swedish bays along the west coast the 1996 year class was only average in size (Wennhage \& Pihl unpubl.); however, in Port Erin in the Irish Sea the 1996 year class also appeared to be exceptionally strong (Nash \& Geffen 2000). The latter corresponds with the findings of Myers et al. (1997). They examined the spatial scale of variability in recruitment in a number of marine, anadromous and freshwater fish species, including plaice, and they concluded that for marine species the correlation scale of recruitment was typically $500 \mathrm{~km}$. The existence of such coherent recruitment fluctuations suggests the influence of wind or water temperature, since only these factors have sufficiently large correlation scales. It at least indicates that the results of this study at the local Balgzand population on an extremely strong year class might also be applicable to other populations.

Acknowledgements. Thanks are due to Ewout Adriaans, skipper of RV 'Griend' for assistance during the field work and to Henk Hobbelink for graphical assistance. This is NIOZ publication no. 3497.

\section{LITERATURE CITED}

Beukema JJ (1991) The abundance of shore crabs Carcinus maenas (L.) on a tidal flat in the Wadden Sea after cold and mild winters. J Exp Mar Biol Ecol 153:97-113

Beukema JJ (1992) Dynamics of juvenile shrimp Crangon crangon in a tidal-flat nursery of the Wadden Sea after mild and cold winters. Mar Ecol Prog Ser 83:157-165

Beverton RJH, Iles TC (1992a) Mortality rates of 0-group plaice (Pleuronectes platessa L.), dab (Limanda limanda L.) and turbot (Scophthalmus maximus L.) in European waters. II. Comparison of mortality rates and construction of life table for 0-group plaice. Neth J Sea Res 29:49-59

Beverton RJH, Iles TC (1992b) Mortality rates of 0-group plaice (Pleuronectes platessa L.), dab (Limanda limanda L.) and turbot (Scophthalmus maximus L.) in European waters. III. Density-dependence of mortality rates of 0 -group plaice and some demographic implications. Neth J Sea Res 29:61-79

Brander K, Houghton RG (1982) Predicting the recruitment of North Sea plaice from egg surveys. ICES CM/G:5, p 1-3

Dapper R (1978) De Balgzand scholgegevens 1975, 1976, 1977. Neth J Sea Res Intern Rep 1978-12, p 1-53

Harding D, Nichols JH, Tungate DS (1978) The spawning of the plaice (Pleuronectes platessa L.) in the Southern North Sea and the English Channel. Rapp P-V Réun Cons Int Explor Mer 172:102-113

Hovenkamp F (1991) Immigration of larval plaice (Pleuronectes platessa L.) into the western Wadden Sea: a question of timing. Neth J Sea Res 27:287-296

Iles TC, Beverton RJH (1991) Mortality rates of 0-group plaice (Pleuronectes platessa L.), dab (Limanda limanda L.) and turbot (Scophthalmus maximus L.) in European waters. 1. Statistical analysis of the data and estimation of parameters. Neth J Sea Res 27:217-235

Kuipers BR (1975) On the efficiency of a two meter beam trawl in juvenile plaice (Pleuronectes platessa L.). Neth $\mathrm{J}$ Sea Res 9:69-85

Kuipers BR (1977) On the ecology of juvenile plaice on a tidal flat in the Wadden Sea. Neth J Sea Res 11:56-91

Myers RA, Mertz G, Bridson J (1997) Spatial scales of interannual recruitment variations of marine, anadromous, and freshwater fish. Can J Fish Aquat Sci 54:1400-1407

Nash RDM, Geffen AJ (2000) The influence of nursery ground processes in the determination of year class strength in juvenile plaice Pleuronectes platessa L. in Port Erin Bay, Irish Sea. J Sea Res 44 (in press)

Nielsen E, Bagge O, MacKenzie BR (1998) Wind-induced transport of plaice (Pleuronectes platessa): early life-history stages in the Skagerrak-Kattegat. J Sea Res 39:11-28

Rauck G (1974) On characteristics of plaice otoliths in the North Sea. Ber Dtsch Wiss Komm Meeresforsch 23: 289-295

Rijnsdorp AD (1989) Maturation of male and female North Sea plaice (Pleuronectes platessa L.). J Cons lnt Explor Mer 46:35-51

Rijnsdorp AD (1994) Population-regulating processes during the adult phase in flatfish. Neth J Sea Res 32:207-223

Rijnsdorp AD, Jaworski A (1990) Size-selective mortality in plaice and cod eggs: a new method in the study of egg mortality. J Cons Int Explor Mer 47:256-163

Rijnsdorp AD, Vethaak AD (1997) Changes in reproductive parameters of North Sea plaice and sole between 1960 and 1995. ICES CM 1997/U:14, p 1-14

Rijnsdorp AD, Daan N, Van Beek FA, Heessen HJL (1991) Recruitment variability in North Sea plaice, sole and cod. J Cons Int Explor Mer 47:352-375

Riley JD, Corlett J (1966) The numbers of 0-group plaice in Port Erin Bay, 1964-66. Rep Mar Biol Stn Port Erin 781965:51-56

Secor DH, Dean JM, Laban EH (1991) Mannual for otolith removal and preparation for microstructural examination. Belle W. Baruch Inst Mar Biol Coast Res Columbia Tech Publ 1991-01, p 1-85

Stevenson DK, Campana SE (1992) Otolith microstructure examination and analysis. Can Spec Publ Fish Aquat Sci 117:1-126

Van der Veer HW (1986) Immigration, settlement, and densitydependent mortality of a larval and early postlarval 0-group plaice (Pleuronectes platessa) population in the western Dutch Wadden Sea. Mar Ecol Prog Ser 29: 223-236

Van der Veer HW, Bergman MJN (1987) Predation by crustaceans on a newly settled 0-group plaice Pleuronectes platessa population in the western Wadden Sea. Mar Ecol Prog Ser 35:203-215

Van der Veer HW, Witte JIJ (1999) Year-class strength of plaice Pleuronectes platessa in the Southern Bight of the North Sea: a validation and analysis of the inverse relationship with winter seawater temperature. Mar Ecol Prog Ser 184:245-257

Van der Veer HW, Ruardy $P$, Van den Berg AJ, Ridderinkhof $H$ (1998) lmpact of interannual variability in hydrodynamic circulation on egg and larval transport of plaice Pleuronectes platessa L. in the southern North Sea. J Sea Res 39:29-40

Von Westernhagen $H$, Dethlefsen V (1997) The use of malformations in pelagic fish embryos for pollution assessment. Hydrobiologia 352:241-250

Wilkinson L. (1989) SYSTAT: the system for statistics: SYSTAT, Inc., Evanston, IL, p 1-638

Zijlstra JJ, Dapper R, Witte JIJ (1982) Settlement, growth and mortality of post-larval plaice (Pleuronectes platessa L.) in the western Wadden Sea. Neth J Sea Res 15:250-272 